\title{
Potential of Red Ginseng Marc for Ethanol Production as a Fermentation Medium
}

\author{
Dong Chung Kim • Man-Jin In*
}

\section{에탄올 발효 배지로서 홍삼박의 활용}

\author{
김동청 · 인만진*
}

Received: 29 July 2013 / Accepted: 30 August 2013 / Published Online: 31 December 2013

(C) The Korean Society for Applied Biological Chemistry 2013

\begin{abstract}
The potential of the red ginseng marc (RGM) for the production of bio-ethanol using enzymatic hydrolysis and fermentation without any additional nutrients was investigated. Reducing sugar content in RGM treated with Viscozyme and Flavourzyme was $101.1 \mathrm{~g} / \mathrm{L}$ and was much higher than that $(7.2$ $\mathrm{g} / \mathrm{L}$ ) in intact RGM. When enzymatically hydrolyzed red ginseng marc (ERGM) was fermented with commercially available dry yeast at $25^{\circ} \mathrm{C}$ for 7 days, the final ethanol concentration reached $29.3 \mathrm{~g} / \mathrm{L}$ with ethanol yield at $0.274 \mathrm{~g}$ of ethanol per $1 \mathrm{~g}$ of solubilized total sugar. Ethanol concentration and ethanol yield of ERGM were drastically increased over $1000 \%$ and $50 \%$, respectively than those of RGM.
\end{abstract}

Keywords enzymatic hydrolysis · ethanol fermentation $\cdot$ red ginseng marc

인삼(Panax ginseng C. A. Meyer)은 한국과 중국 등에서 다양 한 질병을 예방하고 치료하기 위하여 오랫동안 사용되어 온 생 약제이다. 인삼에 함유된 ginsenosides (saponin), acidic polysaccharides, peptides, polyacetylenes, alkaloids, phenolic compounds 등이 다양한 약리효능을 보이는 것으로 알려져 있 다(Attele 등, 1999). 우리나라에서는 인삼의 저장성을 연장하고 약효를 향상시키기 위하여 수삼을 증숙한 후 건조함으로써 홍 삼을 제조하였으며, 홍삼은 항산화, 항암, 항염증, 항바이러스,

D. C. Kim · M. -J. In

Department of Human Nutrition and Food Science, and International Institute of Bio and Health Science, Chungwoon University, Hongseong 350-701, Republic of Korea

*Corresponding author (M.-J. In: manjin@chungwoon.ac.kr)
기억력 개선, 면역증진, 신경조절, 간 보호, 혈당저하, 지방흡수 조절작용 등의 생리활성을 갖는 것으로 보고되어 있다(Kwak 등, 2003). 대부분의 홍삼제품은 홍삼을 물 또는 알코올로 가열 추출하여 제조한 홍삼 추출물을 이용하여 생산되고 있으며, 홍 삼 추출물 제조과정에서 다량의 홍삼 잔사물, 즉 홍삼박이 부 산물로 배출된다(Sung 등, 1985). 홍삼의 기능들이 많은 연구 결과로 알려지면서 홍삼제품의 수요가 늘고 동시에 홍삼박의 폐 기량 역시 증가할 것으로 예상된다. 그러나 일부 홍삼박이 동 물사료와 퇴비로 이용될 뿐 대부분은 폐기되고 있는 실정이다. 홍삼박에는 polyacetylenes계통의 지용성 화합물(Lee 등, 2009) 과 다당체(Lee와 Do, 2002; Tark 등, 2009) 등 여러 가지 유 효성분이 함유되어 있으나 홍삼박의 활용은 매우 미미하다. 홍 삼박의 활용에 대한 연구로는 볶음 처리한 홍삼박의 향기성분 과 관능적 특성(Park 등, 1999), 홍삼박의 다당체 추출조건 최 적화(Chang 등, 2007; Tark 등, 2009), 홍삼박 분말을 첨가한 식빵(Han 등, 2007a), 반죽(Han 등, 2007b) 및 스폰지 케이크 (Park 등, 2008)의 품질특성, 고초균으로 발효시킨 홍삼박 발효 물의 특성(Jung 등, 2010), 느타리버섯 재배 배지로 활용(Lee 등, 2011) 그리고 산란계의 사료에 첨가(Hong 등, 2012) 등이 있다. 홍삼박을 미생물 배양용으로 활용하는 연구는 홍삼박 추 출물을 배지에 첨가하면 효모(Kim 등, 1986a)와 담자균 $(\mathrm{Kim}$ 등, 1986b)의 생육이 향상되며 홍삼박 추출물에 효모의 생육에 필요한 영양성분이나 생육을 촉진하는 물질이 존재한다고 보고 되어 있다. 최근에는 홍삼박 효소분해물을 유산균 배양 $(\mathrm{Kim}$ 과 In, 2010)에 이용하는 연구가 보고된 바 있다. 따라서 본 연구 에서는 홍삼박의 활용에 대한 기존 연구(Kim과 In, 2010)의 연 장으로 다른 배지성분을 첨가하지 않고 홍삼박 효소분해물만을 미생물 배양용 배지로 활용하여 에탄올 발효를 수행하였다. 그 리하여 대부분 폐기되는 홍삼박을 에탄올 생산의 원료로 활용 하기 위한 기초적인 자료를 확보하고자 하였다.

홍삼을 에탄올로 추출한 잔사인 홍삼박을 Greenbio사(Korea) 에서 제공받아 $25 \%$ 농도로 홍삼박 현탁액 $(\mathrm{pH} 5.5)$ 을 만든 후 
Table 1 Effect of enzyme treatments on contents of total soluble solid and carbohydrates in red ginseng marc

\begin{tabular}{cccc}
\hline & Total soluble solid $\left({ }^{\circ}\right.$ Brix $)$ & Total sugar $(\mathrm{g} / \mathrm{L})$ & Reducing sugar $(\mathrm{g} / \mathrm{L})$ \\
\hline Red ginseng marc & $3.1 \pm 0.2$ & $14.0 \pm 0.4$ & $7.2 \pm 0.2$ \\
Enzymatically hydrolyzed red ginseng marc ${ }^{1)}$ & $11.1 \pm 1.0$ & $107.0 \pm 4.1$ & $101.1 \pm 3.9$ \\
\hline
\end{tabular}

${ }^{1)}$ Enzymatic hydrolysis was carried out for $3 \mathrm{~h}$ by two enzymes co-treatment. Reaction conditions: $0.5 \%$ Flavourzyme, $1.0 \%$ Viscozyme, $50^{\circ} \mathrm{C}$ and $\mathrm{pH}$ 5.5. Enzyme dosage was based on solid content.

Table 2 Comparison of ethanol production efficacy between red ginseng marc and enzymatically hydrolyzed red ginseng marc without any additional nutrients

\begin{tabular}{|c|c|c|c|}
\hline & Total sugar $(g / L)$ & Ethanol $(\mathrm{g} / \mathrm{L})$ & Yield $^{1)}(\mathrm{g} / \mathrm{g})$ \\
\hline Red ginseng marc & $14.0 \pm 0.4$ & $2.60 \pm 0.13$ & $0.186 \pm 0.015$ \\
\hline Enzymatically hydrolyzed red ginseng marc & $107.0 \pm 4.1$ & $29.30 \pm 2.27$ & $0.274 \pm 0.031$ \\
\hline
\end{tabular}

${ }^{1)}$ Yield was calculated as the ratio of ethanol concentration to total sugar concentration.

Novozyme사(Denmark)의 상업용 효소인 Viscozyme과 Flavourzyme 을 고형분 기준으로 각각 $1.0 \%$ 와 $0.5 \%$ 가하고 $50^{\circ} \mathrm{C}$ 에서 3 시 간 반응시켜 홍삼박 효소분해물을 제조하였다(Kim과 In, 2010). 가용성 고형물 함량은 당도계(PR-32 $\alpha$ Digital Refractometer, Atago, Japan)를 이용하여 측정하였으며, 총당과 환원당 함량은 포도당을 표준물질로 phenol-sulfuric acid법과 DNS (3,5dinitrosalicylic acid)법으로 각각 분석하였다. 홍삼박에는 약 $70 \%$ 의 탄수화물과 약 $20 \%$ 의 조단백이 함유(Han 등, $2007 \mathrm{a}$; Kim과 In, 2010; Jung 등, 2010)되어 있으므로 홍삼박을 미생 물 배양용 배지로 활용하기 위하여는 수용성 저분자량 화합물 로 분해하여야 한다. 중국 전칠삼(Panax notoginseng) 세포벽은 주로 펙틴 다당체 $(59 \%)$ 와 셀룰로스( $24 \%)$ 로 구성되어 있음 $(\mathrm{Zhu}$ 등, 2005)을 고려하여 탄수화물 분해 복합효소인 Viscozyme ( $\beta$ glucanase, cellulase, hemicellulase, xylanase, arabanase 혼합효 소)과 단백질 분해효소인 Flavourzyme을 처리하여 홍삼박을 분 해하고 상등액의 고형물 함량과 총당, 환원당 함량을 분석하였 다(Table 1). 효소처리에 의하여 가용화된 총당 함량은 $14.0 \mathrm{~g} / \mathrm{L}$ 에서 $107.0 \mathrm{~g} / \mathrm{L}$ 로, 환원당 함량은 $7.2 \mathrm{~g} / \mathrm{L}$ 에서 $101.1 \mathrm{~g} / \mathrm{L}$ 로 크게 증가되었으며, 특히 환원당의 함량이 14 배 향상되어 미생물 생 육에 적절할 것으로 판단되었다. 식용으로 사용할 수 없는 농 업과 임업의 부산물을 에탄올 발효에 이용하기 위해서는 불용 성의 탄수화물 다당체를 발효성 당으로 가수분해하는 당화과정 이 필수적이다(Olsson과 Hahn-Hägerdal, 1996). 산 가수분해는 분해과정에서 미생물 대사에 영향을 주는 독성물질이 생성 (Klinke 등, 2004)될 수 있으므로 효소당화를 활용하였다. 홍삼 박 효소분해에 관한 연구는 cellulase를 처리하여 홍삼박 추출 물의 수율을 $250 \%$ 증가시킨 보고(Kim 등, 1986a)가 있으나, 본 연구에서는 exo-peptidase인 Flavourzyme을 홍삼박에 처리하 면 고형분 회수율이 $31 \%$ 에서 $46 \%$ 로 높아진 결과 $(\mathrm{Kim}$ 과 $\mathrm{In}$, 2010)와 유리 아미노산이 에탄올 발효를 가속시켰다는 결과 (Thomas와 Ingledew, 1990; Klosowsk 등, 2010)를 근거로 단 백질 분해효소를 동시에 처리하여 미생물의 질소원을 공급함과 동시에 발효속도를 향상시킬 수 있도록 유리 아미노산의 생성 을 유도하였다.

가열 $\left(100^{\circ} \mathrm{C}, 20 \mathrm{~min}\right)$ 하여 효소 반응을 정지시킨 홍삼박 효소 분해물 $10 \mathrm{~kg}$ 을 영양성분을 추가하지 않고 에어락이 장치된 발 효용기(model UFP-12, 한국UCD, Korea)에 넣고 시판 건조 효 모(Saccharomyces cerevisiae)인 Fermivin (DSM Food Specialties, Delft, Netherlands) $2.5 \mathrm{~g}$ 을 멸균 생리식염수 $25 \mathrm{~mL}$ 에 현탁시켜

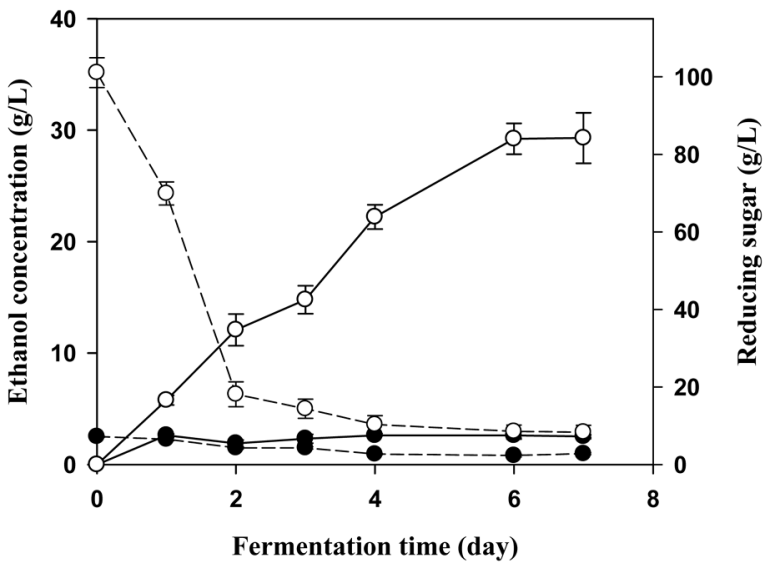

Fig. 1 Ethanol (solid line) and reducing sugar (broken line) concentration using enzymatically hydrolyzed red ginseng marc $(O)$ and red ginseng marc $(\mathcal{O})$ as culture media without any additional nutrient. Fermentation was carried out at $25^{\circ} \mathrm{C}$ for 7 days.

접종한 다음 $25^{\circ} \mathrm{C}$ 의 항온기에서 7 일간 정치 배양하면서 경시적 으로 발효액의 총당, 환원당과 에탄올 함량을 분석하였다. 에탄 올 함량은 가스 크로마토그래피(GC-17A, Shimadzu, Japan)로 분석하였다(In과 $\mathrm{Kim}, 2010)$. 대조구로는 효소 처리하지 않은 홍삼박을 동일한 조건으로 배양하여 비교하였다. 발효 시간에 따른 에탄올과 환원당 함량의 변화(Fig. 1)에서, 에탄올 함량은 홍삼박 효소분해물에는 발효 6일까지 지속적으로 $29.3 \mathrm{~g} / \mathrm{L}$ 까지 증가하였으며, 대조군에서 에탄올 생성은 $2.6 \mathrm{~g} / \mathrm{L}$ 로 매우 미미 하였다. 이와 같은 에탄올 생성량의 차이는 최초 환원당 함량 의 차이에서 기인하는 것으로 사료되었다. 에탄올 생성에 따라 환원당 함량은 지속적으로 감소하여 7일 후 홍삼박 효소분해물 에서는 $101.1 \mathrm{~g} / \mathrm{L}$ 에서 $8.4 \mathrm{~g} / \mathrm{L}$ 로, 대조군에서는 $7.2 \mathrm{~g} / \mathrm{L}$ 에서 2.9 $\mathrm{g} / \mathrm{L}$ 로 감소하였다. 홍삼박 효소분해물을 활용한 발효 효율을 에 탄올 수율로 계산하여 효소분해하지 않은 홍삼박과 비교하였다 (Table 2). 효소분해로 에탄올 생성량은 $2.6 \mathrm{~g} / \mathrm{L}$ 에서 $29.3 \mathrm{~g} / \mathrm{L}$ 로 $1,000 \%$ 이상, 가용화된 총당 대비 수율은 0.186 에서 0.274 로 $50 \%$ 향상되었다. 즉, 홍삼박의 효소분해는 에탄올 생산에 매우 효과적이 방법이었다. Duvernay 등(2013)은 고구마 분말을 amylase와 glucoamylase로 당화시킨 다음 염류 영양분을 추가 하지 않고 에탄올 발효시 $12.5 \%(\mathrm{w} / \mathrm{v})$ 의 가수분해물에서 $33.6 \mathrm{~g} /$ 
$\mathrm{L}$ 의 에탄올이 생산되었다고 보고하였다. 이때 고구마 분말의 에 탄올 수율은 0.269 로 계산되어 본 연구 결과와 매우 일치하는 결과였다. 한편, 리그닌을 함유한 탄수화물 다당체를 에탄올 발 효에 이용하는 경우 탄수화물을 발효성 당으로 분해하기 전에 리그닌 화합물을 제거하는 탈리그닌(delignification)이 필요 (Olsson과 Hahn-Hägerdal, 1996)하며, 원료, 균주, 발효조건 등 에 따라 차이가 있으나 효소당화를 이용한 에탄올 발효의 수율 이 0.3-0.5 범위로 보고(Olsson과 Hahn-Hägerdal, 1996; Rudolf 등 2005; Hernández-Salas 등, 2009)되어 있다. 본 연구에서는 리그닌을 제거하지 않고 발효하여 에탄올 수율이 기존의 결과 보다 다소 낮았으나, 향후 홍삼박의 탈리그닌 방법에 관한 추 가적인 연구가 보완된다면 수율 향상으로 경제성확보에 기여할 것으로 사료되었다.

이상의 결과는 활용도가 낮은 홍삼박의 효소분해는 에탄올 발효에서 에탄올 생성량과 수율을 크게 향상시켜 홍삼박을 에 탄올 발효의 배지로 활용할 수 있는 가능성을 제시하였다.

\section{초 록}

홍삼박을 에탄올 발효의 원료로 활용하기 위하여 홍삼박을 탄 수화물 분해효소와 단백질분해효소로 처리한 결과 환원당의 함 량이 $7.2 \mathrm{~g} / \mathrm{L}$ 에서 $101.1 \mathrm{~g} / \mathrm{L}$ 로 증가하였다. 홍삼박 효소분해물에 영양성분을 추가하지 않고 시판 효모를 접종하여 $25^{\circ} \mathrm{C}$ 에서 7 일 간 발효한 결과 에탄올은 $29.3 \mathrm{~g} / \mathrm{L}$ 까지 생성되었으며 총당대비 수율은 $0.274 \mathrm{~g} / \mathrm{g}$ 로 계산되었다. 이는 대조군보다 에탄올 생산 량은 $1,000 \%$ 이상, 수율은 $50 \%$ 이상 향상된 결과이다.

Keywords 에탄올 발효 · 홍삼박·효소분해

\section{References}

Attele AS, Wu JA, and Yuan CS (1999) Ginseng pharmacology: multiple constituents and multiple actions. Biochem Pharmacol 58, 1685-93.

Chang EJ, Park TK, Han YN, and Hwang KH (2007) Conditioning of the extraction of acidic polysaccharide from red ginseng marc. Kor $J$ Pharmacogn 38, 56-61.

Duvernay WH, Chinn MS, and Craig Yencho G (2013) Hydrolysis and fermentation of sweetpotatoes for production of fermentable sugars and ethanol. Ind Crops Product 42, 527-37.

Han IJ, Kim RY, Kim YM, Ahn CB, Kim DW, Park KT et al. (2007a) Quality characteristics of white bread with red ginseng marc powder. $J$ East Asian Soc Dietary Life 17, 242-9.

Han IJ, Kim YM, and Chun SS (2007b) Characteristics of dough with red ginseng marc powder. J East Asian Soc Dietary Life 17, 371-8.

Hernández-Salas JM, Villa-Ramírez MS, Veloz-Rendón JS, Rivera-Hernández KN, González-César RA, Plasencia-Espinosa MA et al. (2009) Comparative hydrolysis and fermentation of sugarcane and agave bagasse. Bioresour Technol 100, 1238-45.

Hong JK, Bong MH, Park JC, Moon HK, Lee SC, Lee JH et al. (2012) Effect of feeding red ginseng marc on vital reaction in laying hens under stress task. Korean J Poult Sci 39, 63-70.

In MJ and Kim DC (2010) Fermentation characteristics of wild grape (Vitis amurensis) wine prepared with reed (Phragmites communis) root. $J$ Korea Acad-Ind Cooper Soc 11, 1528-33.

Jung HW, Kim JE, Seo JH, and Lee SP (2010) Physicochemical and antioxidant properties of red ginseng marc fermented by Bacillus subtilis HA with mugwort powder addition. J Korean Soc Food Sci Nutr 39, 1391-8.

Kim DC and In MJ (2010) Production of hydrolyzed red ginseng residue and its application to lactic acid bacteria cultivation. $J$ Ginseng Res 34, 3216.

Kim SD, Do JH, Lee KS, and Sung HS (1986a) Effect of ginseng residue extract on yeast growth. Korean J Ginseng Res 10, 1-10.

Kim SD, Do JH, and Lee KS (1986b) Effect of ginseng residue on the growth of Ganoderma lucidum. Kor J Appl Microbiol Bioeng 14, 279-83.

Klinke HB, Thomson AB, and Ahring BK (2004) Inhibition of ethanolproducing yeast and bacteria by degradation products produced during pre-treatment of biomass. Appl Microbiol Biotechnol 66, 10-26.

Klosowsk G, Mikulski D, Czupryñski B, and Kotarska K (2010) Characterization of fermentation of high-gravety maize mashed with the application of pullulanase, proteolytic enzymes and enzymes degrading non-starch polysaccharides. J Biosci Bioeng 109, 466-71.

Kwak YS, Park JD, and Yang JW (2003) Present and its prospect of red ginseng efficacy research. Food Ind Nutr 8, 30-7.

Lee CJ, Han HS, Jhune CS, Cheong JC, Oh JA, Kong WS et al. (2011) Development of new substrate using red ginseng marc for bottle culture of oyster mushroom (Pleurotus ostreatus). J Mushroom Sci Prod 9, 13944.

Lee JW and Do JH (2002) Extraction condition of acidic polysaccharide from Korean red ginseng marc. $J$ Ginseng Res 26, 202-5.

Lee SD, Yoo G, Chae HJ, In MJ, Oh NS, Hwang YK et al. (2009) Lipidsoluble extracts as the main source of anticancer activity in ginseng and ginseng marc. J Am Oil Chem Soc 86, 1065-71.

Olsson L and Hahn-Hägerdal B (1996) Fermentation of lignocellulosic hydrolysates for ethanol production. Enzyme Microb Technol 18, 312-31.

Park MH, Sohn HJ, Jeon BS, Kim NM, Park CK, Kim AK et al. (1999) Studies on flavor components and organoleptic properties in roasted red ginseng marc. J Ginseng Res 23, 211-6.

Park YR, Han IJ, Kim MY, Choi SH, Shin DW, and Chun SS (2008) Quality characteristics of sponge cake prepared with red ginseng marc powder. Korean J Food Cookery Sci 24, 236-42.

Rudolf A, Alkasrawi M, Zacchi G, and Lidén G (2005) A comparison between batch and fed-batch simultaneous saccharification and fermentation of steam pretreated spruce. Enzyme Microb Technol 37, 195-204.

Sung HS, Yoon SK, Kim WJ, and Yang CB (1985) Relationship between chemical components and their yields of red ginseng extract by various extracting conditions. Korean J Ginseng Res 9, 170-8.

Tark K, Cho K, Park KH, Son SM, and Chae HJ (2009) Optimization of extraction conditions for polysaccharide using red ginseng marc. $J$ Ginseng Res 33, 337-42.

Thomas KC and Ingledew WM (1990) Fuel alcohol fermentation: effect of free amino nitrogen on fermentation of very-high-gravity wheat mashes. Appl Environ Mirobiol 56, 2046-50.

Zhu Y, Pettolino F, Mau SL, and Bacic A (2005) Characterization of cell wall polysaccharides from the medicinal plant Panax notoginseng. Phytochemistry 66, 1067-76. 